\title{
Chinese Demand for Agritourism in Rural America
}

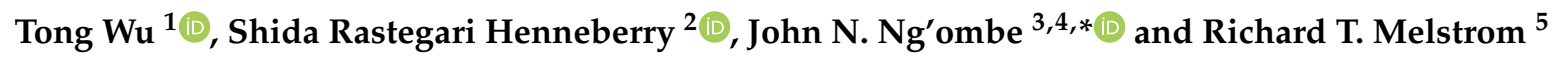 \\ 1 School of Educational Foundations, Leadership and Aviation, and former Master of International \\ Agriculture student, Oklahoma State University, Stillwater, OK 74078, USA \\ 2 Department of Agricultural Economics and Master of International Agriculture Program, Oklahoma State \\ University, Stillwater, OK 74078, USA \\ 3 Department of Agricultural Economics and Rural Sociology, Auburn University, Auburn, AL 36849, USA \\ 4 Department of Agricultural Economics and Extension, University of Zambia, Lusaka 10101, Zambia \\ 5 Institute of Environmental Sustainability, Loyola University Chicago, Chicago, IL 60660, USA \\ * Correspondence: ngombe@okstate.edu
}

Received: 17 March 2020; Accepted: 8 April 2020; Published: 10 April 2020

\begin{abstract}
China is one of the largest sources of outbound tourists coming to the United States. We used data from a choice experiment to determine whether Chinese tourists are interested and willing to pay for agritourism tour packages in which the U.S. state of Oklahoma is the rural destination. Our research is important because agritourism is a growing source of farm revenue, international tourists have potential to accelerate this growth, and China is the largest market for international tourism. Results suggest that, from various agritourism packages offered to them, Chinese travelers are price conscious but willing to pay significant amounts for packages that provide more local foods, that allow them to visit more event and recreation sites, and stay in cabins rather than farmstead accommodations. We also find evidence of significant heterogeneity in Chinese willingness to pay for agritourism attributes.
\end{abstract}

Keywords: farm tourism; willingness-to-pay; mixed logit model; Oklahoma; China

\section{Introduction}

Agritourism has become an important U.S. industry operating at the nexus of the environment, food production, and tourism. An authentic agritourism operation is a working farm in which visitors interact with the farmer, learn about and participate in farming or farm life, and taste authentic agricultural products from the farm [1]. Farmers that market production to tourists often do so to generate additional income, either by increasing sales of existing goods or by developing activities and experiences [2]. Agritourism contributes to farm resilience by diversifying a farm's income-generating portfolio, which in turn helps sustain rural economies [1]. Examples of agritourism goods and activities include wineries, cider mills, "u-pick" self-harvests, farm animal and local wildlife zoos, and farm-stays with overnight accommodations [3-5]. The number of U.S. farms providing agritourism and recreation services rose from 23,350 in 2007 to 28,575 in 2017, an increase of $22 \%$. This shift has important environmental implications as agritourism operations may approach sustainability to a greater extent than many other types of farm ventures [6].

Chinese tourists have significant potential to accelerate growth in the U.S. agritourism industry. China is the leading exporter of tourism dollars to the United States, valued at $\$ 35$ billion in 2018 [7]. China is also the world's largest market for international tourism, a position it has held for nearly a decade. In 2017, outbound tourists from China spent $\$ 258$ billion, essentially double the spending of outbound tourists from the United States, which totaled $\$ 135$ billion [8]. With travel expenses of $\$ 3623$ per person, Chinese tourists could have a significant impact on U.S. agritourism operations [9]. However, current destination choices clearly show that international tourists favor visiting urban and 
natural areas rather than working agricultural lands. For example, Hawaii, New York, Seattle, and San Francisco are the most popular U.S. destinations among Chinese tourists [10] and relatively few Chinese tourists visit the U.S. midwest [11]. The comparatively small impact of international tourism on agritourism in the United States may be due to the preferences of visitors. However, destination choices may also be constrained by a lack of knowledge and marketing. This uncertainty creates a critical need for information about the value of U.S. agritourism to international tourists.

In this paper, we use a choice experiment to examine Chinese outbound tourist preferences for U.S. agritourism. Our objective was to determine Chinese tourists' tastes for potential tour package attributes. In the experiment, subjects indicated their preference between a pair of tourism packages and a would-not-purchase (no-trip) alternative. Both tourism packages featured attributes related to local foods, local sites, tour length, accommodations, and prices in the U.S. state of Oklahoma. Oklahoma provides an ideal agritourism setting because the state lies in the center of the country and has a modest agritourism industry with limited experience with international tourists [12]. Among U.S. states, Oklahoma has the smallest market share of international visitors [13]. The state is therefore a largely untapped market for international agritourists. Nevertheless, the state has the potential to support tourists through an extensive agriculture industry; in 2015, there were 86,600 farms in Oklahoma, covering $78 \%$ of total area [14-16]. Furthermore, Oklahoma's local agritourism opportunities could be attractive to Chinese travelers especially now that agricultural tours have become popular in China [17]. Youxoue et al. [18] reports that China's agritourism market is expanding faster than China's domestic tourism market and that, by 2014, the number of Chinese agritourists were four times more than those in 2010. Mander [19] further indicates an increase in the number of Chinese tourists that prefer agritourism, with about 2.5 billion visiting agritourism sites in China in 2017. Currently, no Chinese travel agencies provide tour routes in Oklahoma [20].

The goal of our research is to better understand international tourists' preferences for U.S. agritourism destinations, the value Chinese outbound tourists specifically have for Oklahoma tour packages, and potential differences across tourists' willingness to pay for specific tour attributes. In studying these issues, we offer several contributions to the literature on agritourism. First, there is growing recognition that consumer preferences are important in understanding the industry [21], and our research focuses specifically on measuring these preferences. In contrast, prior research on agritourism has tended to focus on producers' motivations to enter the market and their product choice [3,22-27]. Second, we estimate the willingness to pay of Chinese outbound agritourists. While there exists a growing literature on willingness to pay for agritourism destinations (e.g., References [17,21,25,26,28-32]), to our knowledge, no studies have used a choice experiment to elicit Chinese tourists' preferences for U.S. agritourism destinations. Filling this gap in the literature is important as Chinese tourists are potentially major consumers of U.S. agritourism products. Third, this study's findings provide insights into the feasibility of marketing tour packages composed of U.S. agricultural and rural destinations to potential Chinese tourists. These insights fill a critical knowledge gap in the sustainability of international tourism flows into the U.S. agritourism industry.

\section{Data}

Survey Design

Primary survey data were collected in 2017, through a survey that was designed in Qualtrics and administered through the internet. After the survey was approved by Oklahoma State University Institutional Review Board (IRB) on September 27, 2017 (IRB Application \# AG1752), we worked with Beijing FangNuoJinLong to deliver it to sample of potential Chinese tourists. Beijing FangNuoJinLong is a travel agency that owns an online database of customers who would be potential future outbound agritourists. Although this sample is not representative of the Chinese population as a whole, it is likely to be representative of individuals who are interested and can afford an international tour. We offered subjects an incentive to complete the survey in the form of discount points on a future travel 
package through Beijing FangNuoJinLong. The points were given to respondents after the conclusion of the survey.

In developing the questionnaire and in designing the choice experiment, we invited two agricultural tourism experts from Oklahoma State University's Agricultural Economics Department to discuss agritourism activities and attributes that could be included in packages for Chinese tourists. After a discussion with these experts, we included the following activities as part of the attributes of an Oklahoma agritourism tour package: 1) the number of agricultural education tour stops, 2) the number of event and recreation tour sites, and 3) the number of sightseeing tour sites. The questionnaire informed subjects that agricultural education tours included activities such as school tours, agricultural technical tours, and historical exhibits, among other activities; event and recreation tours included horseback riding, fishing, nature walks, and attending festivals; and sightseeing tours included wildlife and bird watching, winery visits, and driving tours. We included several more attributes to describe the tour packages in the experiment, including the proportion of local to nonlocal foods (nonlocal being Chinese food) offered during the tour-where $100 \%$ local is an all-American food service, and anything less than $100 \%$ implies that the rest is non-American - the type of accommodation, and the price of the tour package. The types of accommodation included in the survey were hotel, farmstead, and cabin. Each attribute had three to four levels. Table 1 shows the range of package attributes and corresponding levels.

Table 1. Attribute and attribute levels for a hypothetical Oklahoma package tour.

\begin{tabular}{ccccc}
\hline Attribute Name & \multicolumn{4}{c}{ Levels } \\
Price (\$) & 1 & 2 & 3 & 4 \\
Length of stay (days) & 3500 & 4500 & 5500 & \\
Percent of local food (\%) & 7 & 10 & 14 & 4 \\
The number of agricultural education tour stops & 1 & 66 & 100 & 4 \\
The number of event and recreation tour sites & 1 & 2 & 3 & 4 \\
The number of sightseeing tour sites & 1 & 2 & 3 & \\
Types of accommodation & Hotel & Cabins & Farmstead \\
\hline
\end{tabular}

We familiarized subjects with agritourism in Oklahoma by inserting the following paragraph before the choice experiment:

Oklahoma is a state in the southern-central region of the United States. It is a major producer of natural gas, oil, and agricultural products. Oklahoma relies on an economic base of aviation, energy, telecommunications, and biotechnology. There are more than 3.9 million people living in Oklahoma. Oklahoma is a home of agricultural tourism and has several agritourism services and activities that include camping/picnic, hunting, school tours, agricultural technical tours, historical agriculture exhibits, horseback riding, fishing, festivals and fairs, shopping, bird watching, cowboy museums, petting zoos, pickup vehicle driving, and others. Tourists from all over the world, including China are welcome to visit Oklahoma, which is the hub of rural tourism.

The questionnaire then asked subjects to consider the opportunity to travel to Oklahoma to tour agricultural sites and events. The choice experiment presented each subject with 10 choice scenarios, and each scenario contained three choice alternatives. The first and second alternatives were tour packages with different attribute levels, while the last scenario was the option of staying home (and not traveling). We used the Optimal Experimental Design (OPTEX) procedure in Statistical Analysis System (SAS) to generate an experimental design for the 10 choice scenarios [33]. The OPTEX procedure can generate an efficient experimental design for any of these situations. Based on the predetermined attributes and corresponding levels listed in Table 1, there were $3^{4} \times 4^{3}=5184$ possible attribute combinations. A design using all possible combinations is a full factorial design. 
All 5184 potential combinations could not be included in the questionnaire. Thus, for brevity, we used a fractional factorial design. We used the OPTEX procedure to search for the optimal experimental design. We chose the design with 10 choice scenarios and a D-efficiency score of $96 \%$. An example of a choice set is shown in Table 2.

Table 2. Example of a choice set presented to respondents.

\begin{tabular}{cccc}
\hline Attribute & Trip A & Trip B & Stay Home \\
\hline $\begin{array}{c}\text { Length of stay (days) } \\
\text { Percent of local foods (\%) }\end{array}$ & 10 & 14 & $\begin{array}{c}\text { I would prefer not to } \\
\text { take any trips if my only } \\
\text { options were A or B }\end{array}$ \\
$\begin{array}{c}\text { The number of agricultural } \\
\text { education tour stops }\end{array}$ & 33 & 66 & \\
$\begin{array}{c}\text { The number of event and } \\
\text { recreation tour sites }\end{array}$ & 4 & 1 & \\
$\begin{array}{c}\text { Number of sightseeing tour sites } \\
\text { Types of accommodation }\end{array}$ & 1 & 2 & \\
Price of travel package (US\$) & Farmstead & Hotel & \\
\hline
\end{tabular}

The questionnaire included 30 questions. In addition to the 10 choice scenarios, the questionnaire asked subjects about their preferences for sightseeing and recreation activities as well as for their demographic information. We pretested of the survey with 49 Beijing FangNuoJinLong customers. We used feedback from the pretest to improve the final version of the questionnaire. On average, it took $14 \mathrm{~min}$ for a respondent to complete the questionnaire. We had Beijing FangNuoJinLong survey one-thousand members across mainland China, which resulted in complete responses from four-hundred-and-twenty subjects for a $42 \%$ response rate.

\section{Modeling Approach and Estimation}

\subsection{Econometric Framework}

We measured the importance of the tour package attributes using random utility theory (RUT), which assumes that each individual $n=1, \ldots, N$ considers and chooses the alternative with the highest utility among all $J$ alternatives. The $n$th individual's utility from considering and choosing alternative $t$ in the $j$ th choice set is

$$
U_{n j t}=\beta_{n}^{\prime} X_{n j t}+\varepsilon_{n j t}
$$

where $\beta_{n}^{\prime}$ represents individual-specific coefficients, $X_{n j t}$ indexes observed attributes for individual $n$, and alternative $j$ indexes on choice occasion $t$, and $\varepsilon_{n j t}$ is an independently and identically distributed extreme value stochastic disturbance term. We estimated the utility function as a mixed logit following References [34-36]. In the mixed logit, the vector $\beta_{n}^{\prime}$ is random with a probability density function $p(\beta \mid \theta)$, where $\theta$ represents the distribution parameters. Following Reference [37], assuming $\beta_{n}$ is known, the $n$th respondent's probability of choosing alternative $t$ on choice occasion $j$ is

$$
G_{n j t}\left(\beta_{n}\right)=\frac{\exp \left(\beta_{n}^{\prime} x_{n j t}\right)}{\sum_{j=1}^{J} \exp \left(\beta_{n}^{\prime} x_{n j t}\right)}
$$

Similarly, the probability of the observed choice across the alternatives is

$$
S_{n}\left(\beta_{n}\right)=\prod_{t=1}^{T} G_{n j t}\left(\beta_{n}\right)
$$


The unconditional probability of the observed sequence of choices is equal to the conditional probability integrated over the distribution of the parameter value $\beta$ as

$$
P_{n}(\theta)=\int S_{n}\left(\beta_{n}\right) f(\beta \mid \theta) d \beta
$$

Hole [38] suggests that the above framework is broad and can be used to fit models with individual-specific and alternative-specific covariates. However, the log likelihood function for the mixed logit model cannot be solved analytically. Train [35] recommends maximum simulated likelihood estimation, which has been widely used to estimate the mixed logit model. The simulated log likelihood function is

$$
\operatorname{SL}(\theta)=\sum_{n}^{N} \operatorname{In}\left\{\frac{1}{R} \sum_{r=1}^{R} S_{n}\left(\beta^{r}\right)\right\}
$$

where $R$ is the total number of replications and $\beta^{r}$ is the $r$ th draw from the probability density of $\beta \prime, p(\beta \mid \theta)$. More details about maximum simulated likelihood estimation can be found in References [34-38].

\subsection{Empirical Specification}

As in References [39,40], we empirically estimate a random coefficient-based mixed logit model mainly because it can account for unobserved preference heterogeneity. Controlling for any potential heterogeneity is important because not doing so can bias results when such heterogeneity exists. Our online survey captured $N=420$ respondents, and each faced $J=10$ choices with each choice set containing $T=3$ alternatives. The mixed logit model estimated here includes the vector $X_{n j t}$, which comprises all the attributes. Specifically, we estimate

$$
\begin{aligned}
U_{n j t}= & \beta_{0} A S C_{n j t}+\beta_{1} T P_{n j t}+\beta_{2} L F_{n j t}+\beta_{3} A R_{n j t}+\beta_{4} A E_{n j t} \\
& +\beta_{5} S S_{n j t}+\beta_{6} H_{n j t}+\beta_{7} C_{n j t}+\beta_{8} L S_{n j t}+\varepsilon_{n j t}
\end{aligned}
$$

where $A S C_{n j t}$ is the alternative-specific constant for the stay-home alternative, $T P_{n j t}$ is the price of the tour/travel package in US\$, $L F_{n j t}$ is the percent of local foods (\%), $A R_{n j t}$ is the number of event and recreation tour sites, $A E_{n j t}$ is the number of agricultural education tour stops that tourists would visit, $S S_{n j t}$ is the number of nonagricultural sightseeing tour sites that tourists would visit, $H_{n j t}$ is hotel accommodation, $C_{n j t}$ represents cabin accommodation, $L S_{n j t}$ is the length of stay in days, and $\varepsilon_{n j t}$ is the random error.

\subsection{Distributions of Random Coefficients}

Random coefficients from the mixed logit may follow such continuous distributions as normal, lognormal, triangular, or uniform [36]. None of these distributions has all the desirable properties, and thus, their selection remains an area of research [36]. In practice, modelers tend to use the normal distribution when individuals can like or dislike attributes and the lognormal distribution when tastes are expected to have a specific sign. Because coefficients in our model could plausibly take either sign for a respondent, the normal distribution is assumed for all random coefficients. We estimated the mixed logit model in Stata [41] using the mixlogit module developed by Reference [38]. Following Reference [36], all independent variables were assumed random in the initial model, and then we investigated their statistical significance using a zero-based $t$-test. Those in which standard deviations were significantly different from zero were assumed random in the final specification. Because the standard deviation of the variable price of the travel package was not significantly different from zero in the initial model, price of the travel package selected was not treated as a random variable in the final model. We used 500 Halton draws in the simulations. 


\subsection{Willingness to Pay Calculations}

The marginal willingness to pay estimates for each attribute were computed after final estimation of the mixed logit model. Following References [34,35,42], willingness to pay (WTP) for an attribute is the negative coefficient of the attribute divided by the coefficient on price. For example, an agritourist's willingness to pay (WTP) for an additional sightseeing tour in Oklahoma can be computed as

$$
W T P_{S S}=-\frac{\frac{\partial U_{n j t}}{\partial S S}}{\frac{\partial U_{n j t}}{\partial T P_{n j t}}}=-\frac{\beta_{5}}{\beta_{1}}
$$

We calculated the standard errors of the willingness to pay for values in Equation (7) using the delta method [42].

\section{Results}

Table 3 reports descriptive statistics of survey respondents. About $38 \%$ of respondents were male, and on average, respondents were 34 years old. Regarding respondents' annual household incomes, $5 \%$ of the respondents have household incomes of less than or equal to $\$ 10,000$ while about $42 \%$ have household incomes ranging from $\$ 10,000$ to $\$ 29,999$ per year. Further, about $40 \%$ of the respondents have annual household incomes of between $\$ 30,000$ and $\$ 49,999$, while the remaining $12 \%$ of respondents reported annual household incomes of at least $\$ 50,000$. While these household incomes may appear low for a nonlocal tourist, they are consistent with studies of Chinese outbound tourists. For example, Reference [43] finds that Chinese tourists that visited the United States in 2012 had an average household income of $\$ 40,000$. Wang [44] reports that the median household income among Chinese tourists who visited the United States in 2018 was $\$ 45,000$. The income distribution in our sample is centered approximately on the average Chinese household income, which was $\$ 37,417$ in 2017 [45] for three-person households [46]. More than half of the respondents have a bachelor's degree. We also find that most respondents are willing to consider an agritourism vacation outside China.

Table 3. Descriptive statistics of survey respondents.

\begin{tabular}{ccc}
\hline Variable & Mean (\%) & SD (\%) \\
\hline Gender (male $=1,0$ otherwise) & 37.7 & \\
Age (years) & 34.073 & \\
Annual income & $5.0 \%$ & \\
less than $\$ 10,000$ & 42.4 & \\
$\$ 10,000$ to $\$ 29,999$ & 40.4 & \\
$\$ 30,000$ to $\$ 49,999$ & 12.2 & \\
At least $\$ 50,000$ & & \\
Level of education & 20.1 & \\
High school education & 60.8 & \\
College education & 19.1 & \\
Graduate or higher & 73.38 & \\
\hline
\end{tabular}

Table 4 presents estimation results for the mixed logit regression model. Statistical significance of the coefficient on the attribute travel package price implies that, on average, subjects dislike tour packages with a higher price, everything else held constant. The coefficient of the stay-home alternative is negative though it is not significantly different from zero. The positive and statistically significant coefficient on the variable percent local foods implies that, on average, respondents prefer a travel package featuring more local foods than Chinese food. The statistical significance of the positive parameter estimate associated with the number of event and recreation tour sites indicates that, on average, respondents prefer a travel package that provides access to more events and recreation sites. 
In terms of the type of accommodation, results indicate that Chinese tourists prefer hotels and cabins to farmstead accommodations.

Table 4. Mixed logit model results.

\begin{tabular}{ccc}
\hline $\begin{array}{c}\text { Dep. Variable: Choice, Equal to } 1 \text { if Attribute } \\
\text { is Selected, 0 Otherwise }\end{array}$ & \\
\hline Explanatory variables & Mean & SD \\
Travel package price 1000 & $-0.070^{* *}$ & \\
Stay-home alternative & $(0.031)$ & \\
Percent of local foods (\%) & -0.009 & 0.010 \\
& $(0.308)$ & $(0.111)$ \\
The number of event and recreation tour sites & $0.101^{* * *}$ & $0.117^{* * *}$ \\
& $(0.030)$ & $(0.023)$ \\
The number of agricultural education tour stops & $0.139^{* * *}$ & 0.002 \\
The number of sightseeing tour sites & $(0.033)$ & $(0.053)$ \\
& -0.034 & 0.060 \\
Hotel accommodation & $(0.027)$ & $(0.0551)$ \\
& -0.036 & $0.427^{* * *}$ \\
Cabin accommodation & $(0.027)$ & $(0.094)$ \\
Length of stay (days) & $0.353^{* * *}$ & $0.564^{* * *}$ \\
Log likelihood value & $(0.100)$ & $(0.065)$ \\
\end{tabular}

Notes: Standard errors are in parenthesis. ${ }^{* *}$ Statistically significant at $1 \% ;{ }^{* *}$ statistically significant at $5 \%$.

One of the key results from our analysis is the evidence of heterogeneity in attribute preferences. As shown in Table 4, the standard deviations of the random parameters associated with the attributes number of event and recreation tour sites, hotel accommodation, and cabin accommodation are statistically significant at the $1 \%$ level. Using the results in Table 4, we tested for the joint significance of the estimated standard deviations of the parameters of the random coefficients in the model. The likelihood ratio test value is 65.42 ( $p$-value $<0.001)$. Since the $p$-value is so small (i.e., less than 0.01$)$ the null hypothesis that all standard deviations are equal to zero is rejected at the $1 \%$ significance level. These findings imply that, among the stated attributes, there is significant heterogeneity in individual preferences.

Table 5 presents estimates of WTP for incremental changes in the attributes. Results indicate that WTP for a tour package with an increase in local food from $0 \%$ to $100 \%$ is valued at $\$ 1435$ at the mean, with a standard deviation of $\$ 850$. This implies that half of respondents are willing to pay up to $\$ 1435$ for a tour package with all local foods relative to a package with no local foods. Regarding the number of agricultural recreation tour sites, our results indicate that Chinese travelers are willing to pay up to $\$ 1983$ for an additional agricultural recreation tour site. In terms of accommodations, WTP for a tour package with cabin (relative to a farmstead) accommodation is on the margin worth $\$ 6328$ at the mean with and a standard deviation of $\$ 3275$. Note that this WTP value exceeds the maximum price in the experiment. This is because in the experiment many subjects preferred packages with cabin accommodations, generally regardless of the other attributes including price. The model must therefore extrapolate the WTP value. This WTP estimate should therefore be interpreted cautiously. Cabins stand out as a significantly preferred means of accommodation. Moreover, in terms of length of stay, respondents would be willing to pay $\$ 198$ for an additional day they would spend in Oklahoma, though this result is not significantly different from zero. 
Table 5. Willingness-to-Pay (WTP) (\$) results.

\begin{tabular}{cc}
\hline Attribute & \\
\hline & \\
Percent of local foods $(\%)$ & Travel package price \\
& $1435.489^{*}$ \\
The number of event and recreation tour sites & $(850.337)$ \\
The number of agricultural education tour stops & $1983.312^{*}$ \\
& $(1162.445)$ \\
The number of sightseeing tour sites & -495.830 \\
& $(505.891)$ \\
Hotel accommodation & -524.349 \\
Cabin accommodation & $(416.639)$ \\
Length of stay (days) & 5013.836 \\
& $(3153.216)$ \\
& $6328.387 *$ \\
& $(3274.758)$ \\
\hline
\end{tabular}

Notes: Standard deviations are in parenthesis. * Statistically significant at $10 \%$.

\section{Discussion}

This study's objective was to determine Chinese tourists' tastes and willingness to pay (WTP) for potential tour package attributes in Oklahoma. Our data were collected in 2017 through a choice experiment completed by 420 Chinese residents. We estimated a mixed logit model to account for heterogeneity for preferences among the respondents.

Our results are consistent with consumer demand theory in that they indicate that individuals dislike and are less likely to purchase higher-priced tours. That is, Chinese travelers are price conscious and prefer less expensive U.S. agritourism travel packages. In terms of food, we find that respondents prefer a travel package associated with more local foods. Thus, potential Chinese travelers want to eat local, American foods during their agritourism trip. This finding is consistent with published research indicating that tourists consider buying local foods either a very or somewhat important motivation for their visit [47]. Du Rand, Heath, and Alberts [48]; Sims [49]; and Anderssen [50] suggest that local foods and meals not only attract food-interested visitors but also communicate broader experiential benefits at a given destination in terms of cultural impressions and insights. As WTP results show, potential Chinese travelers are willing to pay more for foods that have more local than nonlocal (Chinese) content. This suggests that rural American agritourism producers can promote the local content of their foods to attract Chinese outbound tourists. Furthermore, we found that respondents preferred to visit more event and recreation sites as part of a tour package to Oklahoma. In fact, we found no evidence that they were willing to pay for education or site-seeing tour sites.

Regarding accommodation, we found that Chinese tourists prefer an agritourism travel package featuring cabin accommodations and are willing to pay the least to stay at farmsteads. Examining the same result further, we find that respondents' WTP for a cabin relative to a farmstead is $\$ 6328$ on average, with a significant amount of heterogeneity; the standard deviation parameter indicates that $68 \%$ of respondents are willing to pay between $\$ 3053$ and $\$ 9603$ (i.e., \pm one standard deviation) for cabins over farmstead accommodations, with the remaining $32 \%$ willing to pay either above or below that range. This preference could be driven by amenities associated with cabins, such as private entrances, separate sleeping and living areas, kitchens, and fireplaces that hotels and farmsteads usually lack.

Finally, in terms of length of stay, we do not find a statistically significant parameter estimate for this variable, which means that our respondents' WTP for a given tour package may be largely driven by other factors. This does not mean that willingness to pay is never affected by the length of a trip, 
but that, given a reasonable-length tour package (i.e., seven days), staying an additional day is not worth much without adding more activities.

\section{Conclusions}

This paper presented information about Chinese tourists' preferences for agritourism in rural America, using Oklahoma as the destination setting, by estimating Chinese tourists' willingness to pay (WTP) for a hypothetical agritourism tour package. The preference data came from a choice experiment administered to prospective Chinese tourists. Our results indicate that Chinese tourists have preferences and WTP for specific types of agritourism activities, including visiting event and recreation sites, eating local foods, and staying in cabins rather than farmsteads. Subjects in our study were willing to pay a premium to visit event and recreation tour sites. Subjects were also willing to pay more for tour packages that featured more local foods, which is consistent with prior research that finds travelers are often motivated to travel to an area to try new foods [46]. Among accommodation options, subjects had the largest WTP for cabins, which could be because cabins are perceived as a traditional form of rural accommodation or because cabins include different amenities than hotels and farmsteads. U.S. agritourism businesses that market these attributes will have more appeal to Chinese tourists than businesses that do not. We found no evidence that Chinese tourists value educational and sightseeing tours or stay more than seven days in Oklahoma.

The choices made in the experiment are hypothetical and could differ from actual responses [51]. Future research could use actual choices to verify the agritourism preferences of Chinese tourists. An important caveat is that our experiment did not include images of event and recreation tour sites, sightseeing tour sites, and education tour stops, which could affect the interpretation of these attributes and hence willingness to pay. There was also evidence of a large amount of heterogeneity in Chinese tourists' preferences for agritourism attributes, which was centered around activities in Oklahoma. Of course, preferences for Oklahoma may not be representative of other U.S. states or regions. In any case, our results provide evidence that Chinese tourists are willing to pay thousands of dollars for certain agricultural tour packages, particularly those that provide a large fraction of local foods, that allow visits to event and recreation sites, and that feature cabin accommodations. These findings suggest that there are marketing opportunities in the U.S. agritourism industry to appeal to Chinese tourists and to hence grow farm incomes.

Author Contributions: Conceptualization, T.W., S.R.H., J.N.N., and R.T.M.; formal analysis, J.N.N., and R.T.M.; investigation, T.W., S.R.H., and R.T.M.; methodology, J.N.N., and R.T.M.; resources, S.R.H.; software, J.N.N.; supervision, S.R.H., and R.T.M.; visualization, T.W., S.R.H., J.N.N., and R.T.M.; writing-original draft, T.W., S.R.H., J.N.N., and R.T.M.; writing-review \& editing, T.W., S.R.H., J.N.N., and R.T.M.; All authors have read and agreed to the published version of the manuscript.

Funding: This research was funded by Beijing FangNuoJinLong Conference Service Co., Ltd. grant number AG-17, RS-031 OSU. Additionally, the research was partially supported from the teaching funds generated from Shida Henneberry's classes in the Department of Agricultural Economics and the Master of International Agriculture Program (MIAP) at Oklahoma State University (OSU). Article Publication Charges (APC) were paid by the Department of Agricultural Economics Research Funds at OSU. The research for the first version of this article was conducted to satisfy Tong Wu's creative component degree requirement for the MIAP degree.

Acknowledgments: The authors acknowledge B. Wade Brorsen, Department of Agricultural Economics at Oklahoma State University for his useful comments of the earlier draft of this study.

Conflicts of Interest: The authors declare no conflict of interest

\section{References}

1. Eurac Research 2018. Outcome Statement: 1st World Congress on Agritourism 2018. Available online: https:// agritourism.eurac.edu/wac/wac2018/WAC_2018_Outcome\%20Statement_A4.pdf (accessed on 9 March 2020).

2. McGehee, N.G. An Agritourism Systems Model: A Weberian Perspective. J. Sustain. Tour. 2007, 15, 111-124. [CrossRef] 
3. McGehee, N.G.; Kim, K. Motivation for Agri-Tourism Entrepreneurship. J. Travel Res. 2004, 43, 161-170. [CrossRef]

4. Carpio, C.E.; Wohlgenant, M.K.; Boonsaeny, T. The Demand for Agritourism in the United States. J. Agric. Resour. Econ. 2008, 33, 254-269.

5. Tew, C.; Barbieri, C. The perceived benefits of agritourism: The provider's perspective. Tour. Manag. 2012, 33, 215-224. [CrossRef]

6. Barbieri, C. Assessing the sustainability of agritourism in the US: A comparison between agritourism and other farm entrepreneurial ventures. J. Sustain. Tour. 2013, 21, 252-270. [CrossRef]

7. International Trade Administration (ITA) 2018. Available online: http://travel.trade.gov/outreachpages/ download_data_table/Fast_Facts_2018.pdf (accessed on 9 March 2020).

8. UNWTO. UNWTO Annual Report 2013; UNWTO: Madrid, Spain, 2014; pp. 35-47.

9. China International Travel Monitor (CITM). Indicators of Overseas Tour Expenditure. J. China Tour. Manag. 2017, 5, 34-37.

10. Lu, Z. The Study of Chinese Tourists' Motivations to Canada. J. China Tour. Res. 2011, 7, 345-354. [CrossRef]

11. Fuller, E. Chinese Travel to U.S. Accelerates Dramatically/President Obama's Visa Policy Promises Further Growth. 2015. Available online: http://www.forbes.com/sites/edfuller (accessed on 3 April 2015).

12. Murphy, C. Modeling Revenue and Visitation Patterns of Agritourism Operations in Oklahoma. Master's Thesis, Oklahoma State University, Stillwater, OK, USA, 2015.

13. U.S. Department of Commerce, ITA, National Travel and Tourism Office. Available online: https://travel.trade. gov/outreachpages/inbound.general_information.inbound_overview.asp (accessed on 24 February 2020).

14. Schnelle, M.; Palmer, S.; Criswell, J. 158 Oklahoma Department of Agriculture Inspector Training. HortScience 1999, 34. [CrossRef]

15. Masasi, B.; Taghvaeian, S.; Boman, R.; Datta, S. Impacts of Irrigation Termination Date on Cotton Yield and Irrigation Requirement. Agriculture 2019, 9, 39. [CrossRef]

16. Ng'ombe, J.N.; Boyer, T.A. Determinants of earthquake damage liability assignment in Oklahoma: A Bayesian Tobit censored approach. Energy Pol. 2019, 131, 422-433. [CrossRef]

17. Dax, T.; Zhang, D.; Chen, Y. Agritourism Initiatives in the Context of Continuous Out-Migration: Comparative Perspectives for the Alps and Chinese Mountain Regions. Sustainability 2019, 11, 4418. [CrossRef]

18. Youxue, J.; Shujin, W.; Tsai, C.-C. Study on the Consumption of Agritourism in China. DEStech Trans. Eng. Technol. Res. 2016. [CrossRef]

19. Mander, M. More Chinese Tourists Heading to Rural Villages. 2018. Available online: https://blooloop.com/ link/chinese-tourists-rural/ (accessed on 11 March 2020).

20. Wu, T. Agritourism in Rural America: A Case Study of Oklahoma as a Destination for Tourists from China. Master's Thesis, Oklahoma State University, Stillwater, OK, USA, 2017.

21. Melstrom, R.T.; Murphy, C. Do Agritourism Visitors Care about Landscapes? An Examination with Producer-Level Data. J. Travel Res. 2017, 57, 360-369. [CrossRef]

22. Getz, D.; Carlsen, J. Characteristics and goals of family and owner-operated businesses in the rural tourism and hospitality sectors. Tour. Manag. 2000, 21, 547-560. [CrossRef]

23. Nickerson, N.P.; Black, R.J.; McCool, S.F. Agritourism: Motivations behind Farm/Ranch Business Diversification. J. Travel Res. 2001, 40, 19-26. [CrossRef]

24. Ollenburg, C.; Buckley, R. Stated Economic and Social Motivations of Farm Tourism Operators. J. Travel Res. 2007, 45, 444-452. [CrossRef]

25. Phillip, S.; Hunter, C.; Blackstock, K. A typology for defining agritourism. Tour. Manag. 2010, 31, 754-758. [CrossRef]

26. Ohe, Y.; Ciani, A. Evaluation of Agritourism Activity in Italy: Facility Based or Local Culture Based? Tour. Econ. 2011, 17, 581-601. [CrossRef]

27. Zheng, Z.; Henneberry, S.R.; Zhao, Y.; Gao, Y. Predicting the changes in the structure of food demand in China. Agribusiness 2018, 35, 301-328. [CrossRef]

28. Hearne, R.R.; Salinas, Z.M. The use of choice experiments in the analysis of tourist preferences for ecotourism development in Costa Rica. J. Environ. Manag. 2002, 65, 153-163. [CrossRef]

29. Kenebayeva, A.S. Customer's willingness to pay for agritourism products. Актуальні проблеми економіки 2014, 154, 344-353. 
30. Varmazyari, H.; Asadi, A.; Kalantari, K.; Rezvani, M.R. Estimation of the willingness to pay of citizens for agritourism services case study of Qazvin. Rural Res. 2014, 5, Pe397-Pe422.

31. Chung, J.Y.; Kyle, G.; Petrick, J.F.; Absher, J.D. Fairness of prices, user fee policy and willingness to pay among visitors to a national forest. Tour. Manag. 2011, 32, 1038-1046. [CrossRef]

32. Cullop, J. Assessing Consumer Value through Willingness-To-Pay for Varying Attributes within a Kansas. Ph.D. Thesis, Kansas University, Lawrence, KS, USA, 2019.

33. Atkinson, A.; Donev, A.; Tobias, R. Optimum Experimental Designs, with SAS; Oxford University Press: Oxford, UK, 2007; Volume 34.

34. Revelt, D.; Train, K. Mixed Logit with Repeated Choices: Households' Choices of Appliance Efficiency Level. Rev. Econ. Stat. 1998, 80, 647-657. [CrossRef]

35. Train, K.E. Discrete Choice Methods with Simulation by Kenneth E. Train; Cambridge University Press (CUP): Cambridge, UK, 2003.

36. Hensher, D.A.; Rose, J.M.; Greene, W. The mixed logit model. Appl. Choice Anal. 2005, 30, 605-622.

37. McFadden, D.; Train, K. Mixed MNL models for discrete response. J. Appl. Econom. 2000, 15, 447-470. [CrossRef]

38. Hole, A.R. Estimating Mixed Logit Models Using Maximum Simulated Likelihood. Stata J. Promot. Commun. Stat. Stata 7 2007, 388-401. [CrossRef]

39. Nahuelhual, L.; Loureiro, M.L.; Loomis, J. Using Random Parameters to Account for Heterogeneous Preferences in Contingent Valuation of Public Open Space. J. Agric. Resour. Econ. 2004, 29, 537-552.

40. Niyibizi, B.; Ng'ombe, J.N.; Boyer, T.A. Regulating earthquake risk: Preferences for trade-offs between economic benefits and regulation of produced wastewater injection from hydraulic fracturing. J. Environ. Plan. Manag. 2020, 63, 981-1000. [CrossRef]

41. StataCorp. Stata Statistical Software: Release 15; StataCorp LLC: College Station, TX, USA, 2017.

42. Hole, A.R. A comparison of approaches to estimating confidence intervals for willingness to pay measures. Health Econ. 2007, 16, 827-840. [CrossRef]

43. Adwar, C. Meet the Average Tourist from 9 Different Countries. Available online: https://www.businessinsider. com/the-average-tourist-from-different-countries-2014-5 (accessed on 24 January 2014).

44. Wang, W. China-Travel and Tourism. U.S. Commercial Service Contact for Travel and Tourism Sector. 2019. Available online: https://www.export.gov/apex/article2?id=China-Travel-and-Tourism (accessed on 24 January 2019).

45. Wen, Y. Income and Living Standards across China. 2018. Available online: https://www.stlouisfed.org/onthe-economy/2018/january/income-living-standards-china (accessed on 11 March 2020).

46. EMBR, Esri Michael Bauer Research GmbH 2018, China Average Household Size. Available online: https: //www.arcgis.com/home/item.html?id=1d88d064071b438ab7143fa4c6dbac1e (accessed on 8 March 2020).

47. Dougherty, M.L.; Brown, L.E.; Green, G.P. The Social Architecture of Local Food Tourism: Challenges and Opportunities for Community Economic Development. J. Rural Soc. Sci. 2013, 28, 1-27.

48. Du Rand, G.E.; Heath, E.; Alberts, N. The Role of Local and Regional Food in Destination Marketing. J. Travel Tour. Mark. 2003, 14, 97-112. [CrossRef]

49. Sims, R. Food, place and authenticity: Local food and the sustainable tourism experience. J. Sustain. Tour. 2009, 17, 321-336. [CrossRef]

50. Andersson, T.; Mossberg, L.; Therkelsen, A. Food and tourism synergies: Perspectives on consumption, production and destination development. Scand. J. Hosp. Tour. 2017, 17, 1-8. [CrossRef]

51. Kim, S.W.; Lusk, J.L.; Brorsen, B.W. "Look at Me, I'm Buying Organic": The Effects of Social Pressure on Organic Food Purchases. J. Agric. Resour. Econ. 2018, 43, 364-387.

(C) 2020 by the authors. Licensee MDPI, Basel, Switzerland. This article is an open access article distributed under the terms and conditions of the Creative Commons Attribution (CC BY) license (http://creativecommons.org/licenses/by/4.0/). 